\title{
LEITURA HISTÓRICA SOBRE AS FAMÍLIAS ESCRAVAS: ENTRE AS LEIS ECLESIÁSTICAS EAVONTADE SENHORIAL NO SUDESTE BRASILEIRO (SÉCULO XIX)
}

\author{
Daniel Camurça Correia ${ }^{1}$ \\ Mariana Dionísio de Andrade ${ }^{2}$
}

\begin{abstract}
Resumo
O objetivo do presente artigo consiste em analisar a forma como as famílias escravas, no sudeste brasileiro oitocentista se constituíram, considerando os dispositivos normativos estabelecidos pela Igreja Católica e a vontade senhorial de proprietários de fazendas e vendedores de escravos. É importante observar que os cativos, para além da vontade de seus senhores, ou das prescrições vigentes, a todo custo, tentavam burlar as normas para formar suas famílias. Da mesma forma, discute-se a forma como a lei era aplicada junto aos escravos, para entender de que maneira as normas beneficiavam-nos ou não. Por meio da análise de documentação cartorial, pública e eclesiástica, foi possível observar quais os mecanismos engendrados pelos cativos para reafirmarem seus desejos e sonhos, frente à política de organização familiar da época. Como resultado, verificou-se o hiato existente entre a concessão de matrimônio no contexto do catolicismo monárquico e a própria consideração de cidadania, que não incluía escravos cativos, tornando-os alheios à organização familiar de maneira formal. A partir do estudo, é possível concluir que as discussões referentes à família ainda estão intimamente relacionadas ao sentido religioso, demandando contínua reflexão e evidenciando que a evolução conceitual não acompanhou a realidade social.
\end{abstract}

Palavras-Chave: famílias escravas, casamento, leis eclesiásticas, vontadesenhorial.

\section{INTRODUÇÃO}

Atualmente, no Brasil, pensar a dinâmica da família se tornou desafio recorrente. Seja na esfera política, educacional e social; diferentes segmentos, nos últimos meses, se questionaram a respeito do formato do agrupamento humano dentro do foro íntimo. Ao analisar a história jurídica da constituição das famílias no Brasil, levando em consideração um enfoque histórico e social (BOUTIER; JULIA, 1998), é possível analisar intersecções

\footnotetext{
${ }^{1}$ Doutor em História Social (PUC/SP). Mestre em História (PUC/SP). Graduação em História (UFC). Professor das disciplinas de Filosofia do Direito e Ciência Política do Curso de Direito (UNIFOR). Líder do Grupo de Pesquisa em Filosofia do Direito (UNIFOR-CNPQ).E-mail: daniel.camurca@unifor.br

${ }^{2}$ Pós-Graduanda do Programa de Doutorado em Ciência Política pela Universidade Federal de Pernambuco - UFPE (Bolsista CAPES). Mestre em Direito Constitucional pela UNIFOR. Professora da Disciplina Direito Processual Civil. Especialista em Direito Processual Civil. Pesquisadora do Multidoor Courthouse System. Membro associado do Conselho Nacional de Pesquisa e PósGraduação em Direito - CONPEDI. Membro do Grupo de estudos sobre Poder Judiciário, Política e Sociedade - PRAETOR

/ UFPE (Coord. Prof. Dr. Ernani Carvalho). Membro da Comissão de Ensino Jurídico da OAB/CE. Advogada. E-mail:
} 


\section{Quaestio Iuris}

entre as discussões recorrentes na atualidade sobre os sentidos da família, assim como a forma pela qual diferentes segmentos do passado tentaram elaborar meios de viver e constituir famílias em meio ao debate sobre o que seria possível ou não fazer diante da lei.

No caso do Brasil oitocentista, mais especificamente no sudeste brasileiro, homens e mulheres escravos tentaram constituir suas famílias. A regra era clara: a constituição familiar, de acordo com as Ordenaçôes Filipinas, postulava que a união entre cativos era legítima, desde que firmada pelo matrimônio religioso católico e com o antecipado consentimento do senhor dos escravos (Ordenações Filipinas, 1985).

Porém, a dinâmica da vida demonstrou aos proprietários das fazendas, padres, juízes eclesiásticos, compradores e vendedores de escravos, assim como ao próprio casal, que a vida, o amor e os sentimentos têm seus próprios caminhos - independe do dispositivo normativo em vigor.

O objetivo deste artigo é analisar a forma como se constituíam as uniões formais de acordo com as normas religiosas vigentes no sul mineiro oitocentista. Para homens e mulheres escravos, a vida era muito mais significativa do que estava prescrito pelo senhor, ou pelo ordenamento estabelecido. Viver, morar e constituir família era algo fundamental para alguns cativos. Muitos tentaram constituir família independente das decisões senhoriais, porém, outros decidiram, ou mesmo foram obrigados, a firmar contrato e comprovar a união, ora pela vontade do senhor, ora pela vontade pessoal do casal (ROSEMBERG, 2006).

Não é possível identificar claramente as fronteiras desses desejos. Porém, por meio do arrolamento de dados foi possível descobrir como a Igreja Católica, os senhores de escravos e cativos se organizaram, dentro ou fora da fazenda - ou entre fazendas, para constituírem suas famílias. Na época, assim como hoje, o conceito de família não estava claro para a população. Mas, para a elite política, religiosa e econômica, certamente perpassava pela estrutura matrimonial. O questionamento elaborado neste texto caminha para a compreensão das formas como esta visão de mundo afetava, direta ou indiretamente, a vida diária de homens e mulheres escravos sobre as escolhas de seus parceiros.

No que diz respeito à metodologia de pesquisa, este artigo foi elaborado a partir das leituras e discussões feitas sobre as fontes arroladas no interior de Minas Gerais: registros de batismos, casamentos e óbitos, existentes no Arquivo da Diocese de Pouso Alegre; Escrituras de compra, venda e troca de escravos, existentes no Cartório de Silvianópolis; livros de crônicas e memórias, existentes na Biblioteca Pública Municipal de Pouso Alegre Priciliana Duarte de Almeida. Também foi feita revisão bibliográfica no intuito de elencar, comparar e problematizar as fontes a partir das categorias de análise históricas, jurídicas e religiosas.

Para identificar os problemas registrados na investigação científica e social, na tentativa de fornecer soluções para essas questões ou explicar melhor as inferências localizadas, foi verificado que o uso de estratégias técnicas de

mariana.dionisio@gmail.com 


\section{Quaestio Iuris}

leitura, fichamento e coleta de informações históricas se mostrou ser o mais adequado, evidenciando a dimensão do problema no recorte histórico do século XIX e recorte espacial do contexto colonial e escravista como pano de fundo. (PRZEWORSKI; TEUNE, 1970).

A escolha do método, além de envolver revisão de literatura histórica, obedeceu parâmetros próprios dos desenhos qualitativos, visto que a pesquisa se importa com abordagens pautadas no método discursivo, com informações mais aprofundadas sobre os temas estudados, destacando-se a complexidade das situações sociais e a relação dialógica com a pesquisa. (KING; KHEOANE; VERBA, 1994).

Um elemento central para a presente análise consiste no fato de que o estudo dos fenômenos observados infere que os comportamentos humanos ou sociais trazidos à lume pode ser definido por normas genéricas estabelecidas por meio da observação; e não por justificativa lógica.

\section{O AMOR CATIVO ENTRE O SENTIMENTO PESSOAL E A ORDEMVIGENTE}

Na obra da brasilianista Sandra Graham, Caetana diz não, ${ }^{3}$ a autora apresenta a história de duas mulheres: uma rica, de tradição portuguesa e dona de escravos; a outra, uma escrava que não desejava contrair matrimônio importante para a presente pesquisa. A forma como a autora elabora sua escrita permite que a personagem central uma escrava - demonstre seus sentimentos, no caso, de repugnância a um homem o qual ela não desejava.

Na primavera de 1835, na fazenda Rio Claro, na província de São Paulo, todos os preparativos da capela estavam prontos para o casamento de Caetana e Custódio. Ao findar a cerimônia, ouve a costumeira comemoração, com todos os familiares de ambos os noivos presentes.

No final da festa, tarde da noite, como seria de se esperar, Caetana e seu recém- marido dirigiram-se a casa de seus padrinhos, para a primeira noite do casal. Eis que subitamente - pelo menos para os padrinhos de Caetana - a jovem escrava decidiu não se deitar com seu marido. Ao receber várias ameaças da família, correu aos prantos até a sede da fazenda, em busca de Tolosa, seu senhor ${ }^{4}$.

A história, que por si só é bastante dramática, revela uma série de tensões, regras de mandos e desmandos, na fazenda Rio Claro. Segundo Graham (2005):

Foi o senhor deles que, certo dia, sem consultá-la ou mesmo avisá-la, lhe disse simplesmente que iria se casar. Apesar de seu 'tom positivo', ela reuniu coragem para se recusar. Mas, no final, obedeceu, contra sua vontade e por medo das ameaças de Tolosa: afinal ele era dono dela e 'faria o que quisesse'. Porém, uma vez casada, ela soube o que deveria fazer: recusar o marido. Dessa vez, sua determinação atraiu a ira de outro homem com visível autoridade sobre sua vida, seu tio e padrinho, que ameaçou bater nela se não se submetesse ao marido, como era obrigação de uma esposa. Com poucas escolhas, tarde da noite Caetana correu da casa do tio para a do

\footnotetext{
${ }^{3}$ GRAHAM, Sandra Lauderdale. Caetana diz não: História de mulheres da sociedade escravista brasileira. São Paulo: Companhia das Letras, 2005

${ }^{4}$ Idem. P. 23.
} 
próprio Tolosa. Com sua aflição, ela conseguiu finalmente persuadi-lo de que jamais aceitaria de bom grado o casamento. Tolosa se compadeceu e separou o casal..$^{5}$

A forma como a autora elabora sua escrita permite que a personagem central da história evidencie determinadas preferências. Se Caetana se deitara com Custódio antes do casamento, isto pouco importa. Afinal, era a situação de matrimônio que a incomodava. E isto lhe dava asco. Por isso, considerava repugnante consumar a união. Se ela realmente desejava não se unir a Custódio, jamais poderia dormir com ele, e Caetana sabia disto. Afinal de contas, esta foi a sua maior e mais enérgica ação.

Apesar do visível posicionamento da escrava, em uma sociedade condicionada a respeitar a norma eclesiástica que vigorou durante todo o século XIX, era aceitável que o senhor articulasse o casamento de seus cativos. Assim fez Tolosa, que, sem o consentimento de Caetana, organizou o casamento dela com Custódio. Mesmo sendo bastante incomum para a época, e para os leitores das histórias da escravidão no Brasil, Caetana surge como uma mulher, negra e escrava que se posicionou diante do senhor. Ela não negociou, impôs sua vontade, que, naquele momento, não foi ouvida. Mas já externalizava o que iria acontecer em um futuro não muito distante.

No momento que se casou e não consumou o casamento, segundo Graham (2005), Caetana caiu nos meandros da malha do paternalismo brasileiro. Foi o seu tio/padrinho que não aceitou a postura da escrava, exigindo que deitasse com Custódio de qualquer maneira.

Homens e mulheres da família de Caetana se posicionaram contra sua ação: a jovem deveria consumar o casamento. Como ela não teve apoio em sua própria família resolveu, então, apelar, mais uma vez, para a estrutura de poder vigente. Com um problema desta proporção, Tolosa deveria pensar duas vezes antes de ordenar que a escrava voltasse para a sua família.

Graham propõe a quebra dos paradigmas de interpretações exclusivistas da sociedade escravocrata paulista. Se os escravos eram entendidos como pessoas passíveis e suscetíveis, a autora demonstra que isso nem sempre era concreto, pois Caetana não aceitou simplesmente a ordem dada. E, ao se casar, não só não consumou o casamento, como obrigou o senhor a apoiá-la. ${ }^{6}$

Da mesma maneira, se o senhor era compreendido como o detentor do poder, este, em primeira instância provou seu poder de mando. Mas, ao precisar abrigar Caetana, teve de voltar atrás. A questão, em primeiro momento era: ou aceitava proteger a jovem e rebelde escrava, para resolver o assunto nos dias que se seguiriam, ou teria de arcar com problemas diversos, seja perante seus filhos, seus amigos e os próprios cativos que ameaçavam bater em uma peça que cuidava da casa-grande e das crianças. Era necessário cuidar da escrava doméstica.

\footnotetext{
${ }^{5}$ Idem. P. 24.

${ }^{6}$ Segundo Graham "seria simples descartar Tolosa como um senhor poderoso e Caetana como a escrava indefesa, mas essa interpretação fácil não funciona. Ele, de fato, ordenou que ela se casasse e ela sabia que tinha de obedecer, mas ela lutou e ele cedeu. Um lar quase modelar de ordem patriarcal e escravista se tornou problemático quando Caetana disse 'não'. Por causa dela, toda hierarquia masculina - dono, tio, marido e Igreja - foi perturbada. Portanto, é uma história diferente: um senhor arrependido, uma família escrava severa e uma Igreja indiferente”. Cf: GRAHAM. Op. Cit. Pp.26-7.
} 
O papel de Caetana dentro da fazenda não era pequeno. A moça era uma cativa que tinha de dar conta de uma criança recentemente nascida, outras quatro crianças em tenra idade e mais uma senhora gravemente enferma. Trabalho pesado que Tolosa confiou-a. Agora, Caetana tinha acesso a casa e a intimidade da família. Era basicamente a cativa a responsável pelas crianças. Pois, segundo Sandra Graham:

Em 1832, ao mesmo tempo que exercia o cargo de juiz de paz, Tolosa assumiu a autoridade sobre a companhia de infantaria de Paraibuna, com 52 soldados a pé e trinta de cavalaria, o que atraiu a fazenda Rio Claro ainda mais diretamente para as linhas de poder, obrigações, clientelismo e facções que se estendiam da vila e do município até a província e o império. No mesmo ano, dona Ana Joaquina deu à luz seu quinto filho; ela estava gravemente enferma. Com seu senhor quase sempre chamado para longe da fazenda, Caetana ficou ocupadíssima, tendo de ajudar a cuidar de um bebê, das outras crianças pequenas e de uma dona doente.?

Desta maneira, para Tolosa, a manutenção da ordem e disciplina familiar dependia da forma como Caetana se portava, dentro e fora da casa. Aos olhos da Igreja e, certamente da sociedade que a cercava, Caetana estava errada. A própria Igreja, a qual realizava uma série de exigências para que o casamento de fato acontecesse, tinha uma imagem muito bem definida das mulheres que ousavam desafiar as leis religiosas. ${ }^{8}$

Uma das exigências canônicas era a presença de testemunhas, conhecedores dos noivos, portanto, responsáveis em atestar a idoneidade de ambos e a espontaneidade na realização do sacramento. No caso dos cativos do sul de Minas, essa comprovação era conseguida mediante o depoimento das testemunhas, geralmente em número de duas pessoas; tudo com base nas constituições que limitavam e determinavam as ações dos governos episcopais, conferindo sustentação canônica aos procedimentos. (SANTOS, 2013). Estes sujeitos eram responsáveis por atestar a história dos senhores e dos escravos, caso a Igreja exigisse a comprovação de identidade dos cativos, principalmente para comprovar seus batismos. O senhor tinha de se responsabilizar por conseguir junto à paróquia na qual os cativos tinham sido batizados os documentos comprobatórios dos noivos. Para tal, os senhores solicitavam aos párocos o testamento do batismo.

Para o pagamento do processo, principalmente por meio das penas pecuniárias, de acordo com a documentação arrolada na Cúria de Pouso Alegre, eram os escravos que se responsabilizavam pela finalização das dívidas para com a Igreja (TEIXEIRA, 2006). O objetivo deste rito processual era manter os cativos sob vigilância constante. E agora, casados, em busca da manutenção de suas redes de sociabilidades, mas, ainda presos à fazenda, acabavam por aceitar as exigências dos senhores, assim como da sociedade.

Voltando para a obra de Graham, ela discute com a historiografia social mais recente, a qual afirma que "os

\footnotetext{
${ }^{7}$ Idem. p. 40 .

${ }^{8}$ De acordo com Sandra Graham "a Igreja pedia prova de que nenhum dos noivos tivesse casado antes, o que, por sua vez, exigia que o padre de qualquer paróquia em que eles tivessem vivido quando adultos por mais de seis meses precisava fornecer uma declaração por escrito de que o requerente era solteiro. Obter tal documento era uma tarefa demorada e custosa que supunha alfabetização e habilidades sociais que poucos escravos teriam oportunidade para adquirir. A prova de identidade e elegibilidade, a publicação de banhos, o pagamento do padre para rezar a missa - tudo dependia do empenho dedicado do senhor, bem como de contribuições do próprio bolso". Cf: GRAHAM. Op. Cit. P.51.
} 
senhores estimulavam deliberadamente seus escravos a se casar a fim de controlá-los". Criticando a obra de Robert Slenes (1999), Graham (2005) afirma que:

Escrevendo sobre 'relações de poder' entre senhores e seus escravos no oeste da província de São Paulo e, em especial, a região em torno de Campinas, Slenes descreve 'uma classe senhorial prepotente e frequentemente arbitrária, mas sobretudo ardilosa: uma classe que brande a força e o favor para prender o cativo na armadilha de seus próprios anseios'. Os senhores agiam, segundo ele, 'no intuito de tornar os cativos dependentes e reféns de suas próprias solidariedades e projetos domésticos'. Trata-se de uma linguagem forte que equivale a dizer que os donos de escravos agiam a partir de uma estratégia deliberada de manipulação persistente. Como explicação para as famílias escravas não é convincente, não porque os senhores não fossem astutos e implacáveis, mas porque não há dados que demonstrem uma política coletiva de comum acordo. Pode ser verdade que as fidelidades familiares às vezes tivessem como resultado prender ainda mais os escravos, mas o resultado não prova a intenção, e provas detalhadas e persuasivas da intencionalidade delas ainda não foram encontradas. ${ }^{9}$

A autora é direta, ao questionar, não a intencionalidade dos senhores, mas as possibilidades destas intenções serem elaboradas e praticadas coletivamente, pois era de interesse dos senhores que os cativos permanecessem na terra, utilizando, assim, o matrimônio como um instrumento de fixação do cativo à propriedade. Por outro lado, Graham (2005) chama a atenção para a pouca, ou nenhuma evidência que ateste de fato os interesses dos senhores mediante, por exemplo, a aquisição de cativos. Pergunta-se neste texto: ao comprar os escravos, inclusive em tenra idade, os senhores já tinham determinado o futuro - o casamento - destas pessoas? Ao afirmar que sim, os cativos seriam destituídos da condição de escolherem como formariam suas famílias, que, de acordo com as fontes arroladas, sabe-se que não éverdade.

É fato que muitos senhores determinavam quem casaria com quem. Por outro lado, quando eles determinavam isso? Necessariamente quando as crianças nasciam? Ao se tornarem adultos? É difícil dizer. Para entender o sentido destas perguntas nas fontes eclesiásticas, é preciso aprofundar o conhecimento sobre as mesmas, principalmente em Pouso Alegre, sede da Comarca do Jaguary, no século XIX.

É muito elucidativa a forma como a documentação oficial tratava os escravos, de modo geral, e as mulheres negras, especialmente. Graham chama a atenção para a forma como a população cativa era mencionada em documentos referentes a elas mesmas. Por outro lado, é possível perceber como a população feminina era sutilmente mais referida nas fontes do que os homens. ${ }^{10}$ Geralmente os pais não eram citados, o que significa dizer que seus

\footnotetext{
${ }^{9}$ GRAHAM, 2005, p.56.

${ }^{10}$ Graham afirma que "o que torna o caso de Caetana especial não é a presença dos parentes, mas a oportunidade que nos proporciona de discernir uma rede maior de parentesco que não costuma estar visível nos encontrados na maioria dos documentos. A busca de parentes de sangue ou de casamento é em geral prejudicada pela prática comum dos senhores de designar apenas o prenome de seus escravos. Uma irmã como a de Caetana, casada e morando em sua própria casa, mas listada por seu prenome, estaria perdida para nós porque os documentos raramente preservam as relações de parentesco cruzado de irmãos, tios, primos, sobrinhos, avós e, menos ainda, os laços advindos do matrimônio. Nesse caso, o escrivão não identifica em momento algum a irmã por algum nome. A mãe delas, Pulicena, cujo nome aparece uma única vez, permanece nas sombras, e o pai de Caetana está totalmente perdido para nós. Morto, vendido para outra fazenda, fugitivo? Os documentos não dizem; jamais se referem a ele. Também não sabemos se o tio de Caetana era materno ou paterno, fato que talvez tenha contado nas reações entre eles, mas que permanece fora de nosso alcance". Cf: GRAHAM. Op. Cit.58-9.
} 


\section{Quaestio Iuris}

rastros foram perdidos. A condição de itinerância - inclusive, por causa da venda das peças, fez com que os progenitores fossem sempre invisíveis.

De alguma forma, era desnecessário descriminar o pai. Até porque a prole era sempre pertencente às mulheres, inclusive, decidindo com isso se as crianças seriam ou não livres.

No que diz respeito à constituição dos casamentos, dois aspectos podem ser debatidos. Em primeiro lugar, associada à questão anterior, relacionada ao mando e desmando dos senhores, se as cativas tinham um leque de opções para escolhas ou não de casamentos. Mas uma vez fica clara a frágil linha de dominação do senhor, na decisão de casamento e seus desejos diante do matrimônio.

A segunda questão está relacionada às ações das cativas. Pelo fato de terem opções de casamento, inclusive com não cativos, demonstrando a possibilidade destas mulheres articularem-se de maneiras diversas na sociedade. Pois, no universo de visível presença masculina, para a autora, isto nada mais representara do que a possibilidade das mulheres negras terem à sua disposição grande leque de escolha de parceiros. Se assim quisessem poderiam inclusive trocar de parceiros mais de uma vez.

Para os escravos era interessante o casamento, não só pela constituição de uma família, ou pela possibilidade de sair da senzala, ou para a constituição de uma moradia mais privada, mas também pela condição de receber uma parte da propriedade do senhor. Eles receberiam a oportunidade de morar e trabalhar na terra, a qual seria suficiente para plantar e prover seus familiares. Homens e mulheres escravos, ao ganharem o direito de uso da terra, poderiam garantir o sustento de familiares e agregados. Além, do mais, o que sobrava era vendido - inclusive para o senhor e seus familiares (HUNOLD LARA, 1998).

Ao citar Slenes, Graham afirma que "eles [os cativos] ganhavam seu próprio fogo e a possibilidade de preparar alimentos de acordo com seus gostos e prescrições espirituais, e comê-los com parentes escolhidos, longe das turmas de trabalho". ${ }^{11}$ Ou seja, ao terem suas terras, conseguiam também perpetuar suas práticas religiosas - e mais importante - além de passá-las às gerações seguintes, através dos ritos domésticos.

O leque de atuações de escravos, perante os senhores e suas propriedades não era pequena. As condições de negociações também não eram poucas. Mas, eram frágeis. Segundo Sandra Graham, a morte do senhor não gerava incerteza apenas para seus descendentes, mas também para os cativos e agregados da fazenda.

No caso do Brasil, seguindo a tradição portuguesa, os bens seriam divididos em partes iguais, a não ser que houvesse apenas um herdeiro. Afirma Graham (2005):

A pessoa podia dispor do outro terço como bem quisesse - dizia-se que tinha liberdade testamentária sobre este terço; e, se não houvesse herdeiros necessários, a pessoa podia deixar todo o espólio para um herdeiro de sua escolha. $\mathrm{O}$ valor de todos os presentes, empréstimos e dotes dados aos filhos antes da morte dos pais tinha de ser devolvido ao espólio para a contabilidade final e, se um filho já tivesse recebido mais do que sua parte final dos bens, então devia a diferença ao espólio. O resultado

\footnotetext{
${ }^{11}$ Idem. Pp.61-2.
} 
era que, inevitavelmente, a morte de um senhor fazia com que os escravos fossem divididos entre os herdeiros, junto com os outros bens. ${ }^{12}$

Ou seja, a morte do proprietário da fazenda obrigava que as finanças do local fossem todas contabilizadas e colocadas no papel. Dívida, empréstimos e acordos, escritos ou não, precisavam ser rememorados para que tudo fosse ao inventário. Para os cativos, a maior resultante seria que muitos dos acordos verbais realizados com seus falecidos senhores não eram aceitos pelos herdeiros. De outra maneira, mesmo que os descendentes dessem como firme os acordos entre o falecido e os escravos, na partilha de bens tinha de se reconfigurar uma nova ordem. Escravos eram divididos entre filhos e netos. Mães perdiam seus filhos, mulheres eram separadas de seus companheiros, como mandavam os inventários ou partilhas determinadas pelas instânciaslegais.

Sobre a normatização referente aos procedimentos religiosos e sua relação com os escravos, cumpre destacar o pensamento de Fernando Torres-Londono (2011, p.276):

Para as Constituições Primeiras, na prática da escravidão, os senhores cometeram sérios abusos no
que se refere às obrigações religiosas que tinham para com os escravos; o que acontece em parte, por
não estar estabelecida às obrigações religiosas dos senhores para com eles. Justificados nas mais
variadas escusas, os senhores não se empenhavam no batismo dos escravos. Os escravos
considerados cristãos não conheciam as verdades da religião e não frequentavam os sacramentos. Os
escravos trabalhavam os sete dias da semana, não guardavam o domingo e os dias santos. Tais
situações pediam ajustes e remédios, que introduzissem referências claras dos deveres cristãos e que
da mesma forma mantiveram o caráter universal da legislação.

Uma forma de atenuar a frágil constituição familiar básica entre os escravos era através do batismo, mesmo que não houvesse empenho por parte dos senhores. Na pia batismal nova redes de solidariedade eram tecidas, exatamente para diminuir a zona de abandono que famílias poderiam sofrer, ao serem separadas. Caso o senhor falecesse, ou precisasse pagar suas dívidas com escravos, a rede de compadrio poderia agir. Dificilmente impediria o translado dos cativos para outras fazendas, mas garantia o contato e conhecimento - e provavelmente o acesso - ao familiar vendido. As relações de compadrio, através do batismo, diminuíam as distâncias dos familiares, minimizando o sofrimento daqueles que perderiam ou seriam separados de suas casas.

Para Graham, além do papel prático e social dos padrinhos, estes também tinham responsabilidades espirituais para com as crianças (GRAHAM, 2005). A Igreja Católica sancionava aos padrinhos toda a responsabilidade em guiar os jovens em uma vida reta, de acordo com os preceitos católicos, o que não quer dizer que eram seguidos à risca.

Que os escravos ou forros mais velhos se responsabilizavam pela educação católica das crianças era incontestável. Por outro lado, também é difícil negar o papel destes homens e mulheres na transmissão dos antigos cultos e mitos de origens africanos, para os jovens. Desde cedo as crianças negras aprendiam a lidar com o sincretismo religioso, tão presente no século XIX brasileiro.

A rede de compadrio construída através do batismo era imensa. O número de homens e mulheres que

\footnotetext{
${ }^{12}$ GRAHAM, Sandra Lauderdale. Caetana diz não: História de mulheres da sociedade escravista brasileira. São Paulo: Companhia das
} 


\section{Quaestio Iuris}

poderiam batizar inocentes escravos era considerável. Homens e mulheres livres e moradores da vila, forros, senhoras de escravos, agricultores e cativos faziam parte do grande leque de padrinhos. Porém, não foi ainda encontrado nenhum registro de senhor batizando seu próprio escravo. ${ }^{13}$ Esta regra social a Igreja não interferiu, e provavelmente nunca desejou fazer isso.

Difícil seria o senhor que aceitasse ser padrinho de sua própria peça, impossibilitado, a partir de então, de puni-la com rigor, quando necessário. Da mesma forma, nenhum senhor tinha coragem de contrariar os preceitos católicos, punindo e espancando seu sobrinho, tendo como premissa o papel de protegê-lo sempre. Para evitar tamanho conflito social e espiritual os senhores preferiram não batizar seus escravos, solicitando aos vizinhos, amigos e compadres que fizessem por ele. Em muitos casos, eram os escravos que decidiam quem deveria ir a pia batismal.

\section{O CASAMENTO ESCRAVO: ENTRE O DIREITO E A RELIGIÃO}

Pensar as dimensões do direito e da conquista do direito é um desafio para o historiador social, na medida em que este jogo deve ser estudado dentro do campo de pressões e limites estabelecidos por aqueles que viveram no passado. O objetivo deste texto é entender a construção da liberdade pelo escravo e o direito à liberdade concedido para estes, no qual os cativos desempenharam papel importante para alcançarem o direito de determinarem suas formas de viver e constituir famílias (SILVA, 2004).

Compreender as tensões vivenciadas pela população negra, escrava ou alforriada, apresentando o matrimônio como uma forma de melhor viver, garantindo a continuidade de sua linhagem por meio da organização familiar que julgasse mais adequada é o objetivo da pesquisa. Ao observar a tentativa de lapidar a tradicional família na senzala, é possível vislumbrar o movimento das relações sociais cativas, os quais eram obrigados a desagregar relações já existentes em nome de interesses de senhores escravocratas (CHALHOUB, 1990).

Da mesma maneira, um número infindável de homens e mulheres desarticulava a norma vigente em nome de seus sentimentos, de suas famílias, bem como de suas perspectivas sobre a liberdade - principalmente na forma que a desejavam, a despeito de senhores (SLENES, 1999), apresentando, então, um tenso campo de relações sociais entre os diferentes moradores e trabalhadores das fazendas sul-mineiras.

O papel da Igreja na região do Vale do Sapucaí, durante os oitocentos, é de extrema dependência da ordem

\footnotetext{
Letras, 2005, Pp.65-6.

${ }^{13}$ Segundo Graham, "de acordo com Gudeman e Schwartz, nenhum senhor podia assumir a responsabilidade sagrada por um escravo e ao mesmo tempo afirmar seu direito a 'disciplinar, vender ou fazer trabalhar sem fim' o cativo sem comprometer suas obrigações religiosas ou limitar severamente sua intenção de lucrar com o cativo. Nessa explicação, eles são sustentados pelo viajante do início do século XIX Henry Koster, um inglês residente por muito tempo em Portugal e fluente em português, que afirmou que jamais ouviu dizer que o senhor no Brasil fosse também o padrinho [...] pois tal é a conexão [...] que o senhor jamais pensaria em mandar castigar o escravo'. No entanto, nada no código do paternalismo luso-brasileiro, em sua forma civil ou religiosa, impedia o chefe da família de punir corporalmente aqueles sobre os quais, inclusive membros da família, ele exercia a autoridade doméstica. Ao contrário, o Código filipino, promulgado em 1603 e base no direito civil no Brasil até 1916, lhe permitia de modo expresso o direito a 'castigar' fisicamente
} 
imperial, advinda da Diocese de São Paulo. O número de cartas, notícias, jornais e documentos eclesiásticos de várias espécies mostram que a hierarquia diocesana desejava saber, pormenorizadamente, o que acontecia na jovem comarca do Jaguary, sediada em Pouso Alegre.

Dentro das muitas tarefas para com o rebanho, a Igreja tinha a função de resguardar a alma das famílias constituídas através do sagrado matrimônio. O número de Autos de casamento surpreende os atuais visitantes dos arquivos paroquiais da região, principalmente da atual Diocese de Pouso Alegre. Ali estão contidos os matrimônios de oradores livres, cativos ou forros. Sobre o tema, expõe Fernando Torres-Londono (2011, p. 280):

\begin{abstract}
Nas Constituições Primeiras a administração do sacramento do matrimônio aos escravos recebeu atenção especial. A prática comum de dificultar o casamento dos escravos por parte dos senhores ou de não impedir os frequentes concubinatos, explica tal atenção. Plantéis de predomínio masculinos, menores importações de mulheres, e facilidade de reposição da mão de obra por compra, desestimulavam os senhores a incentivar a formação de famílias onde os escravos se reproduzissem.
\end{abstract}

Mesmo assim, o número de processos de matrimônios é surpreendentemente maior entre a comunidade descendente de portugueses, sobre qualquer outra categoria étnica, principalmente da população trazida da África e de seus descendentes. A desproporção é visível, porém, ao desviar o olhar desta dimensão matematizada, chama a atenção à intenção de seus senhores em estar em dia com as obrigações sagradas da vida. Senhores de escravos advindos das mais variadas regiões da comarca eram compelidos a garantir a salvação de suas almas - e por tabela a de seus escravos -, através da realização da cerimônia perante o juiz dos casamentos da Paróquia de Pouso Alegre.

De acordo com as leis canônicas, salvaguardadas pelas imperiais, todos os senhores de escravos deveriam garantir a decência de suas casas através do fim da promiscuidade latente das senzalas, local de proliferação de desejos libidinosos, que vitimizavam as ingênuas famílias de tradição portuguesa, já enraizadas nas encostas das montanhas, que davam acesso às decadentes minas de Vila Rica e Sabará (PAIVA, 1995).

Para a manutenção da escravaria, muitos senhores eram obrigados a adquirir escravos da região. $\mathrm{O}$ tráfico provincial mineiro não era recente. Pelo menos, é notável o vai-e-vem de crianças recém-nascidas ou iniciantes de seus primeiros passos, atravessando a província, para chegarem à nova morada, principalmente com o advento da agricultura cafeeira, que aumentou substancialmente no século XIX.

No ano de 1849, no dia 26 de janeiro, Francisco casou-se com Marianna, ambos africanos. O problema para Marianna Francisca, proprietária dos cativos, residia no fato de ser sabido que Francisco, anos antes do casamento, mantivera relações sexuais com Isabel - africana, mãe de Marianna. O que traz à luz a possibilidade de pensar nas múltiplas relações sentimentais estabelecidas anteriormente aos Autos de Casamento, questionando, com isso, o interesse real de Francisco e Marianna desejarem, de fato, contrair matrimônio. ${ }^{14}$

Porém, para a realidade católica e econômica da época, os questionamentos se deram por outros vieses:

sua família, seus dependentes e escravos". Cf: GRAHAM. Op. Cit. Pp. 71-2.

${ }^{14}$ Aucto de casamento, Francisco com Marianna (escravos de Marianna Francisca), caixa 52, 1849, ADPA (Arquivo da Diocese de Pouso Alegre). 


\section{Quaestio Iuris}

vol. 09, nº. 02, Rio de Janeiro, 2016. pp.807-826

DOI: $10.12957 /$ rqi.2016.19222

seria, então, Francisco, pai de sua futura esposa? Se esta relação fosse provada, o impedimento seria por causa de uma "afinidade ilícita em linha reta"? O que não poderia ser concebido nem pelo bispado de São Paulo, e, de acordo com o Auto de Casamento, nem pela dona dos cativos, atormentada por sua consciência.

Para evitar vergonhas e desaprovações, tanto da esfera imanente quanto transcendente, Marianna Francisca convenceu os representantes do bispado, em Pouso Alegre, que as relações amorosas que Francisco cultivara com Isabel foram posteriores ao nascimento de Marianna, o que dispensaria os noivos do impedimento.

Desta forma, através do convencimento da senhora, sobre a honra e decência de sua propriedade, foi aceito o argumento de que Marianna Francisca teria plenos direitos de realizar a abençoada união dos africanos.

Os papéis a serem cumpridos pelos senhores e senhoras de escravos caminhavam para a intenção de destituir qualquer imagem de promiscuidade ou depravação dentro de suas terras, evitando-se assim quaisquer admoestações por parte dos sacerdotes. Como bons cristãos, tinham obrigações para com Deus, e, principalmente para com a Igreja Católica, garantindo a salvação de suas almas, bem como de todos aqueles que estavam sobre suas responsabilidades, conforme determinação das Constituições Primeiras do Arcebispado da Bahia de 1707, que dedicaram vinte e três títulos aos cativos.

Não seria incomum encontrar senhores que legitimassem, através do matrimônio, as relações já estabelecidas entre os escravos, em muitos casos, já tendo até filhos. Por outro lado, o casamento, como é percebido no caso acima, se dava, principalmente, entre cativos de localidades diferentes. Para a circulação da economia, da venda de café, bem como da ameaça constante de perdas de peças - seja com as inconveniências das fazendas, ou da ameaça fantasma de uma futura libertação, era necessário estabelecer e implementar formas de garantir o número de trabalhadores na terra.

Apesar do direito adquirido de constituir família, pertencente ao escravo, não era permitido a ele a escolha de condições do casamento e constituição de seu lar. Na verdade, os escravos precisavam estabelecer campos de diálogos, disputas e tensões diversas, muitas vezes físicas, para determinarem como seriam definidos seus dias.

Na propriedade de Bernardino da Cunha, na Vila de Jaguary, no ano de 1836, os escravos Manoel e Marcelina tiveram Adão. No mesmo ano Adão foi batizado, tendo como padrinhos Antonio e Margarida. ${ }^{15}$

Com 20 anos de idade, Adão foi vendido para o Alferes Severiano Dias Ferras da Lús. Ao morar em Pouso Alegre, depois de 10 anos, casou-se com Maria Vicencia, filha de Calisto e Inocência - já falecida. Maria Vicencia era de Pouso Alegre e foi comprada por Dona Maria José de Freitas Vilhena, esposa do alferes.

Então, em 1866, Adão e Maria Vicencia foram levados à Igreja para a realização do matrimônio. Porém, O promotor José Joaquim Vieira de Carvalho se opôs ao casamento, sem justificativa explícita. De qualquer modo, o casamento ocorreu, sendo testemunhas Anicizio José de Araújo, solteiro, de 50 anos, negociante e residente em

\footnotetext{
${ }^{15}$ Justamento de estado livre e de baptismo, Adão (escravo de Severiano Dias Ferrás da Lus), caixa 50, 1866, ADPA.
} 


\section{Quaestio Iuris}

vol. 09, nº. 02, Rio de Janeiro, 2016. pp.807-826

DOI: $10.12957 /$ rqi.2016.19222

Pouso Alegre e Laurindo Gonçalvez Vilhena Braga, solteiro, da mesma cidade, de 29 anos e empregado público. ${ }^{16}$

Pensar em casamento e constituição da família católica, tradicional, oriunda dos preceitos europeus, através da cultura portuguesa, instalada nas províncias imperiais do Brasil - o que não excluiria a recente província das Minas Gerais, em meio aos escravos, significa compreender a presença de homens e mulheres que intervinham das mais diversas maneiras no jogo das relações sociais daqueles que desejavam participar da construção de seus dias. Este era o papel dos compadres e comadres, que apoiavam e tornavam factuais todos os argumentos acerca das realidades das fazendas ou sobre o passado dos cativos.

O discurso dirigido ao juiz deveria ser coeso e coerente. Não poderia haver distorções, segundas intenções e, muito menos, desencontros de informações. Por isso, o casamento em si, era um ato que se constituía desde a aquisição de escravos, pelo encontro dos futuros pretendentes, acertando as falas e documentos com as testemunhas e chegando, finalmente ao escrivão e ao Juiz.

A fronteira entre a propriedade de um bem e a oportunidade deste bem constituir uma família lícita, em primeira instância, ao olhar jurídico, pertencia ao dono do cativo. Eram os senhores que deveriam se deslocar de suas propriedades longínquas, para encontrarem o juiz dos casamentos, combinar dia, hora, preço, atestados diversos necessários - principalmente de comprovação de batismo - e testemunhas do ritual religioso.

No rito, eram os senhores e testemunhas que respondiam a todas as perguntas referentes aos "contraentes", inclusive na cessão de depoimentos destes. Os cativos não tinham o direito adquirido de fala direta, frente ao Juiz. A obrigação dos "contraentes" era apenas estarem presentes no dia e hora marcado, com suas respectivas documentações e o valor a ser pago - diga-se, doado - à Caixa Pia.

Em mais de 50 processos de matrimônio, todos faziam alusão à mesma prática: eram os próprios cativos que realizavam a contribuição à Caixa Pia. Ou seja, apesar do interesse e pressão dos seus proprietários, os cativos dispendiam suas rendas, geralmente provenientes de trabalhos de ganho, para cumprir com as obrigações eclesiásticas. Conforme transcrição da norma no 303 das Constituições do Arcebispado da Bahia de 1707 (on line, p.125):

Norma. 303. Conforme a direito Divino, (1) e humano os escravos, e escravas podem casal' com outras pessoas captivas, ou livres, e seus senhores the não podem impeclir (2) o Matrimonio, nem o uso dene (3) em tempo, e lugar conveniente, nem por esse respeito os podem tratar peiol', nem (A) vender para outros lugares remotos, para onde o outro por ser captivo, ou pode ter outro justo impedimento ou não possa seguir, e fazendo o contrario peccão (5) mortalmente, e tomão sobre suas consciencias as culpas de seus escravos, que por este temor se deixão muitas vezes estar e permanecer em estado de condemnação (in litteris)

A história das famílias, em busca da manutenção de suas memórias e tradições, muitas vezes, permaneceu esquecida, podendo apenas ser vislumbrada nas fontes. É o caso da família de Paulo criolo e Romana crioula, 4a geração de uma família escrava pousoalegrense.

\footnotetext{
${ }^{16}$ Aucto de casamento, Adão com Maria Vicencia (escravos do alferes Severiano Dias Ferrás da Lus), caixa 58, 1866, ADPA.
} 
Filhas de pais desconhecidos, Luiza e Silveria tiveram histórias diferentes. Silveria, de acordo com a fonte arrolada tem suas histórias de lutas e sentimentos encobertos pelo negro véu do deslembrar.

No caso de Luiza, sua história teve considerável trama. Ao manter relações com um homem não revelado, Luiza teve duas filhas: Joaquina e Luciana. A jovem Luciana casou-se com João, os quais tiveram Paulo criolo. Joaquina, por sua vez, teve uma filha com Francisco, a qual se chamava Romana crioula.

Depois da negociação e insistência de seu senhor, Jose Theodoro Pereira, no dia 13 de maio de 1847, foi realizada casamento dos oradores Paulo e Romana. Como era de se esperar o casamento não foi tranquilo, o juiz do casamento desejava saber por que deveria aceitar o casamento fruto de um impedimento de $3^{\circ}$ grau por

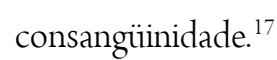

Neste caso, chama a atenção à postura de Romana, a qual alegou incisivamente que eles eram tementes a Deus e reconheciam o pecado o qual desejavam praticar, e que por pertencerem a um senhor empobrecido, e se não seguisse as suas instruções e ordens, correria o risco de não ter nenhum outro pretendente para se casar. Ou seja, a Igreja Católica seria a responsável em impedir o casamento de duas pessoas que reconheciam seus pecados, mas que desejavam subjugá-los a Deus, através do sacramento.

Para a realização do casamento, então, deveriam cumprir as penitências seguintes: que se abstivessem de toda e qualquer comunicação (antes do matrimônio); rezariam dez rosários; ofereceriam dez coroas à Sagrada Mte.(sic), Paixão de Nosso Senhor Jesus Christo pelas almas do purgatório; jejuariam por um dia; varreriam a Igreja da Matriz de Pouso Alegre uma vez cada um; confessariam e comungariam; e, por fim, serviriam a Igreja por tempo de oito dias.

Os oradores alegaram que seria um incômodo permanecerem fora de suas casas por tanto tempo. Solicitaram a comutação das penitências corporais em penas pecuniárias. No dia 16 de maio foi permitida aos "supprahentes" a comutação das penitências em pena pecuniária de $4 \$ 820$ réis. Assim, acabaram, então, por se utilizarem de suas economias, para que pudessem livrar-se dos trabalhos de limpeza da Matriz da cidade.

Neste momento, o senhor se ausentava de qualquer possibilidade de contribuir no pagamento da dívida religiosa. Ora, se os escravos, assim, como o senhor, eram pobres, deveriam, então, trabalhar ao invés de gastarem suas parcas economias. Porém, é possível observar que ao terem o direito de contrair rendas com seus próprios trabalhos - desde que não interferissem na lógica de exploração de seus senhores, ou soubessem muito bem negociar as obrigações diárias - ultrapassando as expectativas de seus donos, assim como dos representantes de Deus na terra, estas famílias possuíam dinheiro, e o utilizavam quando necessário.

A partir do momento que os cativos utilizavam seus recursos para a manutenção da família, aos moldes católicos, entende-se pela nova formação da estrutura de relações sociais entre senhores e escravos, na medida em que

\footnotetext{
${ }^{17}$ Aucto de casamento, Paulo Criolo com Romana Criola (escravos de Jose Theodoro Pereira), caixa 51, 1847,ADPA.
} 


\section{Quaestio Iuris}

estavam mais inseridos na vida social. Mas, é importante não perder de vista que estas famílias investiam na seguridade do casamento religioso, apontando mais uma possibilidade de estruturar a família, de tal maneira que impossibilitasse sua futura desagregação. De acordo com o brasilianista Robert Slenes (1999),

Nas regiões de grande lavoura no Rio de Janeiro e em São Paulo, e nas áreas agropecuárias mais dinâmicas do Sul de Minas Gerais, a escravidão na primeira metade do século XIX era quase literalmente "africana". Recenseamentos da época indicam que cerca de $80 \%$ dos cativos adultos (acima de 15 anos) nessas regiões provinham da África. ${ }^{18}$

O senhor tinha de levar em consideração que a elaboração das obrigações, e, da mesma forma, as interpretações sobre o trabalho escravo por parte deste grupo de africanos eram diferenciadas em relação aos conhecidos ladinos. Suas formas de entender e constituir famílias estavam intimamente ligados ao universo africano. Constituir suas "choças" aos moldes do continente africano era desejo comum destes homens e mulheres, para se distanciarem da repressorasenzala.

Afinal de contas, era obrigação do senhor retirar o casal da senzala e dar-lhes parte da terra da fazenda para construírem uma moradia. Na nova casa, a família teria o direito de plantar e criar animais, desde que dividisse sua pequena produção agrária com seus senhores. Assim, seria possível aos escravos cuidarem de seus filhos - fora da senzala -, adquirirem a possibilidade da compra da alforria, através do trabalho de ganho e ainda supriam as necessidades alimentares de seus senhores. Segundo Slenes:

\footnotetext{
Se o escravo e a escrava que se casavam podiam ter em mira, como objetivo realista, conseguir mais recursos para si e mais controle sobre sua economia doméstica, eles também podiam aspirar a levar adiante, com mais sucesso, projetos de médio e longo prazos. Enfim, se o fogo conjugal oferecia mais garantia de um presente de "gente", vivido à luz do passado, ele também abria mais esperanças para um digno futuro. Os frutos da roça, da criação e da exploração do mato tinham um valor de troca, além de sua utilidade imediata. ${ }^{19}$
}

Ou seja, estes homens e mulheres poderiam, dentro de suas condições do presente e projeções de futuro estabelecer situações monetárias para o bem viver. Não era difícil encontrar em Minas Gerais, em diferentes anos e fazendas, escravos que utilizavam suas economias no intuito de se livrarem das obrigações católicas. Era necessário permanecer na fazenda, não para atender as necessidades de seus senhores, mas para manterem condições materiais para juntarem dinheiro, principalmente para adquirirem as alforrias da esposa, em primeiro lugar, e do marido, em um segundo momento.

\section{ENTRE A UNIÃO MATRIMONIAL E SEPARAÇÃO ECONÔMICA}

No ano de 1852, em Bom Retiro, Germano e Benedicta, escravos do Tenente Manoel Luis de Moraes, tiveram Joaquim, batizado no mesmo ano, tendo como padrinhos os seus avós, Lisbão e Maria, então pertencentes a

\footnotetext{
${ }^{18}$ SLENES, op. Cit., P. 142.

${ }^{19}$ SLENES, op. cit., P. 150.
} 


\section{Quaestio Iuris}

Lauriano de Moraes. $^{20}$

Anos depois, Joaquim foi vendido a Vicente Ferreira de Abreu. Na fazenda do senhor Vicente, conheceu Antonia Domingues de Jesus, nascida e batizada em Pouso Alegre, livre, filha natural de pai incógnito e de Antonia de Jesus - Já falecida. Joaquim, então, desejou se casar com Antonia, no ano de 1882. Porém, era sabido que o casamento não poderia ser concretizado, pois Joaquim mantinha relações sexuais com Maria, irmã de Antonia.

Entretanto, pelo fato dos oradores já estarem morando juntos, foi decido pelo juiz dos casamentos que Joaquim e Antonia poderiam se casar, desde que pagassem o erro com penas corporais - deveriam passar uma semana a serviço da Igreja. Contudo, os oradores afirmaram não terem meios para se deslocarem à Igreja para realizarem o trabalho, solicitando a comutação para penas pecuniárias. Feito o acordo, o casamento se concretizou de fato. Foram testemunhas João José de Barros Cobra, casado, de 31 anos, negociante e José de Carvalho Motta, de Portugal, 50 anos, casado enegociante.

As penas corporais - geralmente realizações de trabalhos de limpeza e manutenção da Matriz de Pouso Alegre -, aplicadas pela Igreja, demonstram necessariamente formas de correção aos oradores que não estavam em dias com os dogmas católicos. Ora, para muitas destas famílias o casamento religioso, em alguns casos, nada mais era do que a regulamentação de uma realidade já existente, pelo fato dos senhores não quererem discórdias junto aos párocos, que ocasionalmente visitavam as famílias rurais nos almoços de domingo e combinavam o quanto antes o ritual. Afinal de contas, a Igreja, segundo os párocos, deveria abençoar toda e qualquer união. Segundo afirma Patrícia Ferreira dos Santos (2009), a pressão sobre os senhores e sobre os párocos para que os cativos fossem inseridos aos ritos católicos persistia, levando bispos a "lembrar aos senhores de escravos de seus débitos com o Senhor Supremo" (p.36).

Não era desconhecida pelas famílias escravas, rurais ou urbanas, a realidade daqueles que não conseguiam manter sua família. Muitos eram vendidos. Em fins do século XIX, parcelas significativas de escravos foram vendidas, compradas ou trocadas. Em muitos momentos eram feitas negociações de escravas acompanhadas de suas crianças. Porém, dificilmente pôde ser arrolado um caso de escravo vendido com mulher e filhos.

Ao realizar uma pequena cartografia do tráfico provincial mineiro, foi possível encontrar a história de Graciano, o qual foi vendido, em maio de 1866, para João Domingues da Silva. A única referência ao Graciano e seus familiares, assim como para todos os adultos era mais ou menos a mesma “(...) Graciano, de cor preta, de vinte annos de idade mais ou menos, solteiro, natural desta provincia, filho de Ritta, lavrador (...)”. ${ }^{21}$

Apesar de desejarem casar seus escravos, muitos ainda permaneceram solteiros, ou, pelo menos, suas condições familiares não permitiram manter seus entes próximos. O que leva a entender que os senhores mantinham

\footnotetext{
${ }^{20}$ Justificativa em favor dos oradores, Joaquim (escravo de Vicente Ferreira de Abreu) e Antonia de Jesus, caixa 60, 1882,ADPA.

${ }^{21}$ Escriptura de compra e venda do escravo Graciano (outorgante: José Custodio Braga e outorgado: José Domingues da Silva), 1876,
} 
as famílias intactas o quanto era possível e conveniente. Dependia muito do interesse do comprador. Por outro lado, não era interessante nem para outorgante e outorgado negociar um escravo disposto a qualquer coisa para reaver seus familiares. Ou seja, uma vez separados mãe e filho, o comprador só conseguiria de fato dores de cabeça. Pois, de todas as formas estas pessoas iriam tentar se reencontrarem, fugindo de seus antigos ou novos senhores.

No caso das mulheres, pode-se citar o caso de Ritta, que foi vendida com sua família, descrita nestas condições:

(...) na presença dos quais pelo outorgante Antonio Joaquim da Fonseca me foi dito, que em data de sette de Janeiro do anno de mil oitocentos e settenta contractou de vender ao outorgado Manoel Pinto de Andrade de vender-lhe os escravos Ritta, de cor preta, de vinte e sette annos de idade, solteira, natural desta provincia, de serviço domestico; José, de cor preta, [com dose anos de idade] solteiro, natural desta provincia; e Felícia, de sette annos de idade, natural desta provincia; cujos escravos possue com livre e geral administração e sem embaraço algum (...). ${ }^{22}$

Independente dos interesses dos senhores, as escravas deveriam ser compradas e vendidas dentro de condições muito especiais. Geralmente os senhores compravam cativos adultos por causa do conhecimento de ofício que carregavam consigo. O preço a ser pago, então, inclúa, o valor das crianças. O comprador deveria saber e arcar com esta responsabilidade. O interessante é que esta condição não era imposta pelo vendedor, mas pela cativa.

Como seus companheiros não eram vendidos juntos, a situação da família acabava se alterando também. $\mathrm{O}$ que não significa dizer que os homens não tivessem interesse em manter a família unida. Mas, que nas relações tensas entre senhores e escravos, algumas vezes os escravos ganhavam e em outras, não.

A linha do direito ao casamento e manutenção da família era extremamente frágil, dependia de múltiplos fatores, ligados às relações pertencentes à terra, ao paternalismo e a grande família portuguesa. No sul de Minas Gerais é difícil separar a quantidade de casamentos e separações forçadas. Principalmente se as artimanhas realizadas pelos cativos não eram compreendidas como formas de melhor viver.

Segundo Patrícia Ferreira dos Santos (2009, p. 37), acerca dos casamentos dos cativos em Minas Gerais:

(...) estabelecia-se que capelães não deveriam receber escravos sem licença in scripta dos párocos para se casar; deveriam lhes tomar juramento verbal, assegurando-se de que se casavam por sua livre e espontânea vontade; e que o mesmo juramento deveriam prestar os senhores, se os cativos não estavam jurando por medo.

Se estes homens e mulheres constituíram famílias a partir das bênçãos dos senhores e da Igreja, e com isso conseguiram construir uma casa, automaticamente, significava dizer que os sentidos da liberdade também se reconstituíram, colocando em dúvida o significado tradicional da liberdade, da fuga e da violência. Como afirma, Chalhoub,

(...) Em outras palavras, o problema é reconhecer a presença da classe senhorial na forma como os escravos pensavam e organizavam seu mundo e, ao mesmo tempo, entender que os escravos instituíam seu próprio mundo mesmo sob a violências e as condições difíceis do cativeiro, sendo que

CS (Cartório da Cidade deSilvianópolis).

${ }^{22}$ Escriptura de compra e venda dos escravos Ritta, José e Felícia (outorgante: Antonio Joaquim da Fonseca e outorgado: Manoel Pinto de Andrade), 1876,CS. 
a compreensão que tinham de sua situação não pode ser jamais reduzida às letras senhoriais de tal situação. Mais recentemente, vários historiadores perceberam que uma forma de analisar esta questão seria a investigação daquilo que os negros, assim como os proprietários e os governantes, tinham a dizer a respeito do significado da liberdade naqueles anos decisivos de crise da instituição de escravidão e de guerra civil. ${ }^{23}$

Ou seja, pensar as dimensões dos direitos matrimoniais implica observar discursos e interesses de escravos e senhores na construção das famílias cativas. Por outro lado, não se deve imaginar este campo de sociabilidade como algo pacífico. Era um espaço de disputa e conflito, no qual cativos disputavam, brigavam e negociavam, através de suas múltiplas manifestações e condições para estabelecerem suas vontades.

O caso mais conhecido - e esquecido - em Pouso Alegre, sobre a tensão estabelecida entre o entendimento de matrimônio de um senhor e a vontade de formar família de cativo, ocorreu na primeira metade do século XIX. Para pôr em discussão a memória edificada sobre os cativos e a constituição das famílias escravas, no ano de 1846, de acordo com o cronista Eduardo A. O. Toledo, no livro Estórias do Mandu (TOLEDO, 1998), foi realizado em Pouso Alegre o primeiro e último enforcamento da cidade.

Conforme esse texto, no ano de 1823, em São José das Formigas (atual Paraisópolis), distrito da vila de Pouso Alegre, o senhor de escravos José Alves Siqueira da Paixão promoveu o casamento de uma de suas escravas com Antonio Congo. Passavam-se 12 anos após o casamento e o senhor continuava se servindo da cativa na cama, até que Antonio Congo, no dia 24 de novembro de 1835, esfaqueou Paixão até a morte, sendo preso por isso.

11 anos depois ocorreu o julgamento do cativo africano, o qual, no dia 15 de abril, foi condenado ao enforcamento em praça pública. Por volta do dia 30 de junho de 1846, a sentença de morte foi lida no largo do Rosário (atual Praça João Pinheiro), local do Pelourinho, no qual se iniciou o cortejo, que percorreu as principais ruas de Pouso Alegre, com a sentença "lida em voz alta" ${ }^{24}$ Ao retornarem ao largo, Antonio Congo foi enforcado.

A partir da história contada por Toledo, é possível compreender sobre que balizas os cronistas e memorialistas pousoalegrenses tentavam forjar o passado da cidade. A história causa intriga, na medida em que tenta edificar na memória a imagem de uma cidade onde não se mata, não se recrimina ou se pune publicamente com a morte os assassinos, pois o enforcamento ocorrido foi o único. Por outro lado, um crime cometido contra as elites, ou "moradores decentes", deveria ser punido severamente.

Ao observar mais cuidadosamente os autores responsáveis por contar a história de Pouso Alegre, pode-se ver que a presença dos trabalhadores e, principalmente, dos cativos é inexistente nos textos. Seja pela tipificação dos trabalhadores das ruas e pedintes, os quais se tornam risíveis para os leitores (TOLEDO, 1997); seja pela condescendência que o autor tem perante cativos e famílias pobres, destituindo-os do quadro de sujeitos ativos (CARVALHO, 1982); ou, ainda, por completo esquecimento (e mesmo desinteresse) em observar o cotidiano dos

\footnotetext{
${ }^{23}$ CHALHOUB, op. cit., P.26.

${ }^{24}$ TOLEDO, op. cit., p.28.
} 


\section{Quaestio Iuris}

trabalhadores comuns (GOUVÊA, 2004), os cronistas e memorialistas embelezam e organizam a história de Pouso Alegre através da tradição familiar colonial portuguesa (FIGUEIREDO, 1997).

No que diz respeito à disputa entre senhores e escravos, simplesmente não há nenhum tipo de menção, discussão e, principalmente, punição aos senhores que desagregavam as ordens mundanas e religiosas em nome das famílias constituídas aos olhos de Deus e dos Juízes. Afinal de contas, Paixão desestabilizava o casamento de Antonio Congo.

O casamento de escravos era exigido por parcelas significativas da população do sul de Minas, por outro lado, estes mesmos setores entendiam que, mesmo as famílias constituídas, era de direito do senhor decidir sobre a vida e morte de suas peças. Logo, o agressor aos olhos da população do passado e do presente é o escravo, que tentou defender sua honra e família. E não o senhor, que rompeu com laços que ele mesmo corroborou para que fossem estabelecidos.

\section{CONSIDERAÇÕES FINAIS}

Enfim, pensar o direito ao matrimônio convida o pesquisador da história do direito a vislumbrar as limitações dos desejos daqueles que tentaram constituir famílias diante da operação religiosa e senhorial. Na lógica do poder instituído, a concessão da legítima família deveria agraciar os interesses da população branca rural, que cada vez mais se urbanizava. Neste ínterim, restaria aos escravos burlar, mentir e enganar, incessantemente, para superarem as expectativas de seus donos, para, finalmente, constituírem sua família.

Se a concessão ao matrimônio tinha a função de melhorar a imagem da católica monarquia brasileira, por outro lado, ajudou a evidenciar os dilemas da evangelização da população cativa da cristandade, caridade e, principalmente, do paternalismo dos senhores, apresentando incessantemente, os mecanismos que dispunham aos escravos para legitimarem suas vontades, seus sonhos, recordações e projetos para o futuro.

Em razão do condicionamento por meio do discurso evangelizador, os escravos tinham o direito ao matrimônio, mas não à cidadania. Para os escravos, pouco importava o direito ao casamento ou o próprio sentido da cidadania, pois desejavam de fato construir seus dias a partir de suas realidades, sendo elas concedidas, ou, mormente conquistadas.

Pensar na atualidade brasileira, após analisar as diferentes tentativas em reafirmar a pluralidades de sentidos do conceito família implica, certamente, no fato de que ainda existe um longo caminho pela frente. Em pleno século XXI, discussões referentes à família ainda possuem seu fundamento nas concepções religiosas exigem forte reflexão. Não pelo que deveria ser, mas pela história de lutas e conquistas daqueles que não foram beneficiados pelas leis no passado, exigindo reflexão sobre como as leis, hoje, poderiam ser elaboradas e aplicadas, para o benefício daqueles que 
desejam alcançar a cidadania todos os dias, o que expõe o problema das fontes do direito de então e do direito contemporâneo.

\title{
HISTORICAL APPROACH ON THE SLAVE FAMILIES: BETWEEN THE ECCLESIASTICAL LAWS AND MASTER'S WILL IN BRAZILIAN SOUTHEASTERN ( NINETEENTH CENTURY)
}

\begin{abstract}
The purpose of this article is to examine, in the context of the nineteenth century Brazilian southeast, how slave families were formed bringing to the analysis the regulatory requirements established by the Catholic Church and the master's will of farm owners and slave sellers. It is significant to note that the captive slaves, beyond the will of their masters, or the existing prescriptions, in all possible ways, tried to circumvent the rules to form their families. Similarly, we discuss how the law was applied with the slaves in an attempt to understand whether the normative acts could benefit them in some way. From the survey conducted by notary's office document, literature review and ecclesiastical sources, we observed wich mechanisms were engendered by captive to reaffirm their desires and dreams, confronting the family organization policy of the period. As a result, we must consider the existence of a gap between the marriage grant in the context of monarchical Catholicism and the very consideration of citizenship, wich does not include captive slaves, making them oblivious to the formal family organization. It concludes that the discussions about family are still closely related to the religious sense, demanding continuous reflection and showing that the conceptual evolution did not follow the social reality.
\end{abstract}

Keywords: slave families, marriage, ecclesiastical laws, master's will

\section{REFERÊNCIAS}

BRASIL. 1707. Constituições do Arcebispado da Bahia de 1707. Disponível em: <file://C:/Users/hp/Downloads/000056491.pdf>. Acesso em: 06 dez. 2015.

BOUTIER, Jean e JULIA, Dominique. 1998. Passados Recompostos; campos e canteiros da história. Rio de Janeiro: Editora UFRJ: Editora FGV.

CARVALHO, Cônego Augusto José de. 1982. Terra do Bom Jesus. Pouso Alegre: Artes Gráficas Irmão Gino Ltda.

CHALHOUB, Sidney. 1990. Visões da liberdade: uma história das últimas décadas da escravidão na corte. São Paulo. Companhia das Letras.

FIGUEIREDO, Luciano Raposo de Almeida. 1997. Barrocas famílias: vida familiar em Minas Gerais no século XVIII. São Paulo:HUCITEC.

FREYRE, Gilberto. 1997. Casa-grande \& senzala: formação da família brasileira sob o regime da economia patriarcal. $32^{a}$ edição. Rio de Janeiro: Record. 
GOUVÊA, Octávio Miranda. 2004. História de Pouso Alegre. 2a. ed. Pouso Alegre: Academia Pousoalegrense de Letras.

GRAHAM, Sandra Lauderdale. 2005. Caetana diz não: História de mulheres da sociedade escravista brasileira. São Paulo: Companhia das Letras.

HUNOLD LARA, Silvia. "Escravidão, Cidadania e História do trabalho no Brasil”. In: Revista Projeto História. São Paulo: Educ, (16), fev. de 1998. Pp.25-38.

KING, Gary; KEOHANE, Robert; VERBA, Sidney. 1994. Designing Social Inquiry: scientific inference in qualitative research. New Jersey: Princenton University Press. LONDOÑO, Fernando Torres. As Constituições do Arcebispado da Bahia de 1707 e a presença da escravidão. Disponível em: < http://www.humanas.ufpr.br/portal/cedope/files/2011/12/As- $\quad$ Constitui\%C3\%A7\%C3\%B5es-doArcebispado-da-Bahia-de-1707-e-a- $\quad$ presen\%C3\%A7a-da-escravid\%C3\%A3o-Fernando-Torres-Londono.pdf>. Access in: December 6th. 2015.

ORDENAÇÕES FILIPINAS. 1985. Reprodução fac-simile da edição feita por Candido Mendes de Almeida no Rio de Janeiro em 1870. Lisboa: Calouste Gulbenkian.

PAIVA, Eduardo França. 1995. Escravos e Libertos nas Minas Gerais do século XVIII: estratégias de resistência através dos testamentos. São Paulo: Annablume. PRZEWORSKI, Adam; TEUNE, Harry. 1970. The logic of comparative social inquiry. New York: Wiley-Interscience.

ROSEMBERG, André. 2006. Ordem e burla: Processos sociais, escravidão e justiça em Santos, década de 1880. São Paulo: Alameda.

SANTOS, Patrícia Ferreira dos. 2009. O mundo celestial no cativeiro: mensagens pastorais à população escrava e aos senhores das minas à época de dom Frei Manoel da Cruz (1748-1764). In: Revista Territórios e Fronteiras. v.2 n.1 Jan/Jun 2009. Pp. $27-44$.

2013. Carentes de Justiça: juízes seculares e eclesiásticos na confusão de latrocínios nas Minas Setecentistas. Tese de Doutorado. São Paulo: Faculdade de Filosofia, Letras e Ciências Humanas da Universidade de São Paulo.

SILVA, Cesar Mucio. 2004. Processos-crime: escravidão e violência em Botucatu. São Paulo:Alameda.

SLENES, Robert W. 1999. Na senzala, uma flor: Esperanças e Recordações na Formação da Família Escrava - Brasil Sudeste, século XIX. Rio de Janeiro: Nova Fronteira.

TEIXEIRA, Maria Lúcia Resende Chaves. 2006. Família escrava e riqueza na comarca do Rio das Mortes: O distrito de Lage e o Quarteirão do Mosquito. São Paulo: Annablume; Coronel Xavier Chaves: Prefeitura Municipal de Coronel Xavier Chaves. TOLEDO. Alvarina Amaral de Oliveira. 1997. Uma história que já vai longe... Niterói: GráficaFalcão.

Trabalhoenviadoem 17 deoutubrode2015.

Aceitoem07 dejaneirode2016. 